\title{
Інокентій Гізель
}

\section{Opus totius philosophiae (Твір про всію філософію),} логіка, трактат «De distinctionibus (Про розрізнення), розділи 3-7.

\begin{tabular}{|c|c|}
\hline $\begin{array}{l}{ }^{(1)} \text { Caput 3. In quo de distinctione } \\
\text { scotistica quaeritur }\end{array}$ & $\begin{array}{l}{ }^{(1)} \text { Розділ } 3 . \quad \text { В } \quad \text { якому } \\
\text { скотистичне розрізнення }\end{array}$ \\
\hline $\begin{array}{l}{ }^{(2)} \text { Censent scotistae distinctionem eam, } \\
{ }^{(3)} \text { quae absque ope intellectus subsistit }{ }^{(4)} \text { et } \\
\text { quam nos realem vocamus, }{ }^{(5)} \text { distinctionem } \\
\text { ex natura rei appellandam esse. }{ }^{(6)} \text { Idque } \\
\text { forte ideo, (7) quia naturae rerum habent } \\
\text { quandam nonrepugnatiam, ut inter se } \\
\text { distinguantur. }{ }^{(8)} \text { Hanc rursus dividunt in } \\
\text { distinctionem realem et distinctionem } \\
\text { formalem. }{ }^{(9)} \text { Illa nam, quae ex natura rei } \\
\text { absque intellectus fictione }{ }^{2} \text { distinguuntur, } \\
\text { inquiunt scontistae, }{ }^{(10)} \text { in duplici sunt } \\
\text { differentia. }{ }^{(11)} \text { Quaedam, quae de potentia } \\
\text { Dei absoluta possunt saltem non mutuo } \\
\text { saparari, }{ }^{(12)} \text { sicut materia et forma, }{ }^{(13)} \text { quae } \\
\text { ex natura rei nullo intellectus beneficio } \\
\text { disntiguuntur et mutuo possunt separari, } \\
{ }^{(14)} \text { potest nam materia existere sine forma } \\
\text { et forma sine materia }{ }^{3} \text {. }{ }^{(15)} \text { Et sicuti forma et } \\
\text { illius unio, }{ }^{(16)} \text { in quibus forma potest } \\
\text { separari ab unione, }{ }^{(17)} \text { et si haec sine forma } \\
\text { non possit existere }{ }^{(18)} \text { et ita non mutuo } \\
\text { separari possunt. }{ }^{(19)} \text { Haec extrema } \\
\text { separabilia // [100v] sive mutuo, sive non } \\
\text { mutuo realiter distiguuntur, iuxta } \\
\text { scotistarum opinionem, in quo conveniunt } \\
\text { cum thomistis. (20) Alia sunt extrema, } \\
\text { inquiunt scotistae, (21) distincta ex natura } \\
\text { rei, (22) quorum neutrum enim Divinitus ab } \\
\text { altero potest separari, }{ }^{(23)} \text { licet a parte rei } \\
\text { habeant entitates et quidditates distinctas, } \\
(24) \text { ita ut sint plures entitates et quidditates } \\
\text { seu formalitates, }{ }^{(25)} \text { non vero plura entia, } \\
{ }^{(26)} \text { quia illorum distinctio versatur inter } \\
\text { entitates et conceptibilitates, (27) non vero } \\
\text { inter entia. }{ }^{(28)} \text { Et haec distinctio vocatur ex } \\
\text { natura rei formalis }{ }^{(29)} \text { et ita consistere } \\
\text { potest cum identitate reali. }\end{array}$ & 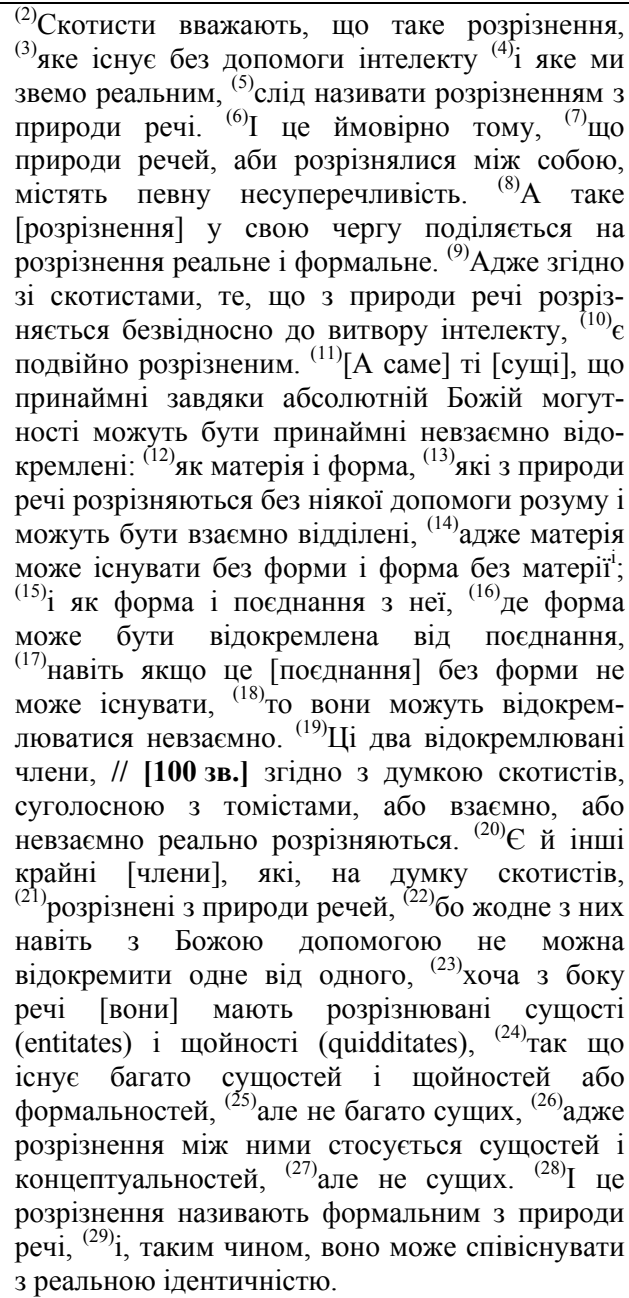 \\
\hline $\begin{array}{l}{ }^{(30)} \text { Ex his inferunt aliam esse distinctionem } \\
\text { formalem, }{ }_{(31)} \text { aliam disinctionem } \\
\text { formarum. }{ }^{(32)} \text { Distinctio formarum est, } \\
{ }^{(33)} \text { quae v.g. intercedit inter albedinem et } \\
\text { nigredinem, }{ }^{\left({ }^{34)}\right.} \text { quae non est distinctio ex } \\
\text { naturae rei formalis, }{ }^{(35)} \text { sed distinctio ex }\end{array}$ & $\begin{array}{l}{ }^{(30)} 3 \text { цього вони виводять, що одне - це фор- } \\
\text { мальне розрізнення, }{ }^{(31)} \text { a інше }- \text { розрізнення } \\
\text { форм. }{ }_{(32)} \text { Розрізнення форм, }{ }_{(33)} \text { наприклад, } \\
\text { встановлюється між білістю і чорнотою. }{ }^{(34)} \mathrm{I} \\
\text { воно є не формальним, }{ }_{(35)} \mathrm{a} \text { реальним } \\
\text { розрізненням } 3 \text { природи речі, }{ }^{(36)} \text { що існує не }\end{array}$ \\
\hline
\end{tabular}

${ }^{2}$ fictione ] виправлено, було functione

${ }^{3}$ Realis est illa distinctio inter illa на полі 


\begin{tabular}{|c|c|}
\hline $\begin{array}{l}\text { natura rei realis, }{ }^{(36)} \text { quae non solum est } \\
\text { inter entitates, }{ }^{(37)} \text { sed inter entia }{ }^{4} . \\
\text { (38) Distinguuntur nam albedo a nigredine, } \\
\text { tanquam ens ab ente. }\end{array}$ & $\begin{array}{l}\text { тільки між сущостями, }{ }^{(37)} \text { але й між сущими }{ }^{11} \text {. } \\
{ }^{(38)} \text { Адже білість від чорноти розрізняють як } \\
\text { суще від сущого. }\end{array}$ \\
\hline $\begin{array}{l}{ }^{(39)} \text { Distinctionem vero ex natura rei } \\
\text { formalem }{ }^{5} \text { ex quinque capitibus indagantur } \\
\text { scotistae, }{ }^{(40)} \text { videlicet ex exclusione, }{ }^{(41)} \mathrm{ex} \\
\text { defintione, }{ }^{(42)} \mathrm{ex} \text { descriptione, }{ }^{(43)} \mathrm{ex} \\
{\text { demonstratione }{ }^{(44)} \text { et reduplicatione. }}^{(45)} \text { Quoties nam aliqua ita se habent, }{ }^{\left({ }^{4}\right)} \mathrm{ut} \\
\text { unum aliud excludat a sua ratione formali, } \\
{ }_{(47)} \text { vel diversa definitione essenitiali aut } \\
\text { descriptiva explicetur, }{ }^{(48)} \text { qui explicatur } \\
\text { aliud, }{ }^{(49)} \text { aut de ipso demonstratur aliquid, } \\
{ }_{(50)} \text { quod non demonstratur de alio, }{ }^{(51)} \text { vel } \\
\text { denique in quantum tale dicatur aliquid de } \\
\text { illo, }{ }^{(52)} \text { quod non dicatur in quantum tale de } \\
\text { alio, }{ }^{(53)} \text { tum unum ab alio ex natura rei } \\
\text { formali distinguuntur. }\end{array}$ & 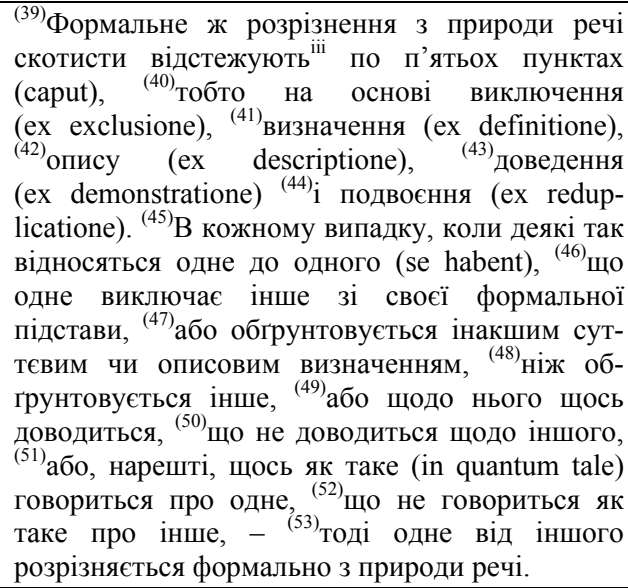 \\
\hline 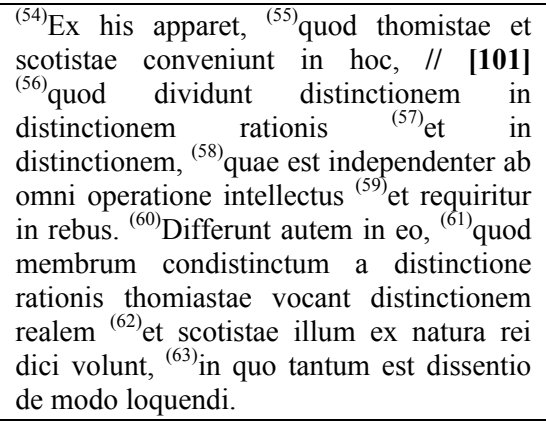 & 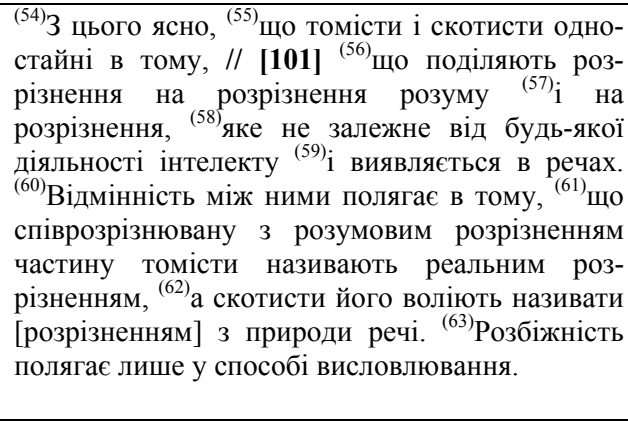 \\
\hline $\begin{array}{l}{ }^{(64)} \text { Asserunt ultra scotistae distinctionem } \\
\text { ex natura rei condistinctam a ratione } \\
\text { rationis }{ }^{6},{ }^{(65)} \text { contrahi per duplicem allatam }{ }^{7} \\
\text { inferiorem, }{ }^{(66)} \text { videlicet per distinctionem } \\
\text { ex natura rei realem, }{ }^{(67)} \text { et hanc } \\
\text { distinctionem habere, affirmant, omnia } \\
\text { entia, }{ }^{(68)} \text { quae thomistae distinguunt } \\
\text { distinctione, }{ }_{(69)} \text { opposita distinctioni } \\
\text { rationis, quae absolute realis vocatur, }{ }^{(70)} \text { et } \\
\text { per distinctionem ex natura rei formalem, } \\
{ }_{(71)} \text { qua scotistae affirmant distingui omnes } \\
\text { entitates, }{ }_{(72)} \text { quas thomistae tantum } \\
\text { distinguunt distinctione rationis } \\
\text { ratiocinatae, }{ }^{(73)} \text { habente tale fundamentum } \\
\text { a parte rei, }{ }^{(74)} \text { quod est aptum pluribus } \\
\text { conceptibus. }\end{array}$ & 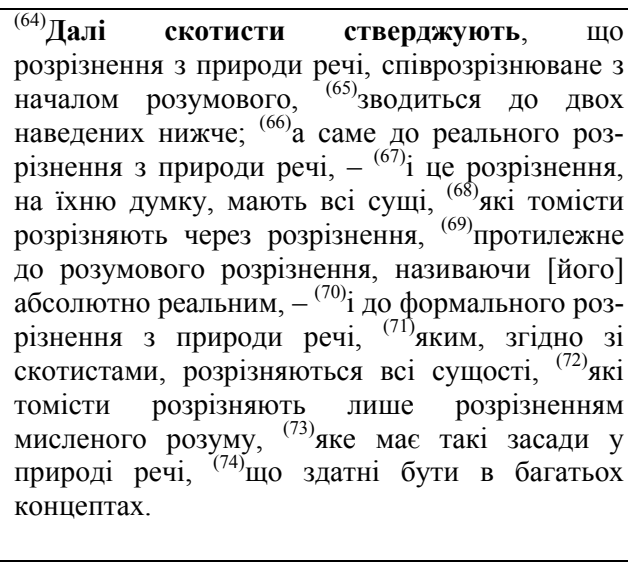 \\
\hline
\end{tabular}

\footnotetext{
${ }^{4}$ Non inter duas entitates, sed inter duo entia completa на полі

${ }^{5}$ Distinctio autem formalis consistit inter duas entiatates in uno ente reperitas на полі

${ }^{6}$ ratione rationis ] можливо, це - помилка, має бути distinctione rationis

${ }^{7}$ allatam ] нечіктко
} 
${ }^{(75)} \mathrm{Ex}$ his inferes distinctionem mediam, ${ }^{(76)}$ quam scotistae defendunt, ${ }^{(77)}$ non esse distinctionem ex natura rei ut sic, ${ }^{(78)}$ quia distinctio ex natura rei communis est, iuxta illorum acceptionem, speciali distinctioni, ${ }^{(79)}$ quam ipsi propugnant et communi, ${ }^{(80)}$ quam cum thomistis admittunt, ${ }^{(81)}$ sed distinctionem ex natura rei formalem independentem ab intellectu, ${ }^{(82)}$ quae autem minor sit, quam realis et maior sit quam rationis, ${ }^{83)}$ ideo media appellatur.

\section{${ }^{(1)}$ Caput 4. // [101v] De distinctione virtuali}

${ }^{(2)}$ Distinctio virtualis est unitas aequipollens multitudini, ${ }^{(3)}$ id est tunc inter duo reperitur distinctio virtualis, ${ }^{(4)}$ quando illa duo sunt unum quod actu a parte rei, ${ }^{(5)}$ sed quod aequipolleat multis, ${ }^{(6)}$ quae alibi realiter actu distinguuntur. ${ }^{(7)} \mathrm{V}$.g. homo, cum sit idem realiter, ${ }^{(8)}$ habens virtutem vegetativam, sensitivam et rationalem, ${ }^{(9)}$ quae sunt idem cum anima realiter, (10) aequivalet multis animantibus realiter distinctis. ${ }^{(11)}$ Dicimus ergo distincta virtualiter illa extrema, ${ }^{(12)}$ quae in re nullam habent distinctionem, ${ }^{(13)}$ sed realiter omnino sunt idem, (14) praestant tamen idem, quod praestarent, ${ }^{(15)}$ si realiter essent distincta.

${ }^{(16)}$ Ideoque et praedicata, ${ }^{(17)}$ quae ex se dicunt contradictionem, ${ }^{(18)}$ ratione huius virtualis distinctionis in eadem entitate potest reperiri absque ulla repugnantia, ${ }^{(19)}$ ita ut illa praedicata ex se contradictoria, ratione subiecti $^{8}$ quasi exuant contradictionem, ${ }^{(20)}$ et absque illa in eandem confluant identitatem ${ }^{9}$. ${ }^{(21)}$ Vocatur haec distinctio etiam fundamentalis seu radicalis, ${ }^{(22)}$ quia praebet fundamentum intellectui, ut abstrahat unam formalitatem ab altera. ${ }^{(23)}$ Non nunquam appellatur distinctio haec potentialis extrinseca, ${ }^{(24)}$ sive quod idem est [distinctio] ${ }^{10}$ rationis praecisivae, ${ }^{(25)}$ quia formalitates virtualiter distinctae habent potentiam, ut distinguantur extrinsece, ${ }^{(26)}$ hoc est ut actibus intellectualibus realiter distinctis concipiantur
(75)3 цього виводиш, що проміжне розрізнення, ${ }^{(76)}$ яке захищають скотисти, ${ }^{(77)}{ }^{\text {не }}$ є розрізненням 3 природи речі як таке, ${ }^{(78)}$ тому що, на їхню думку, розрізнення 3 природи речі $\epsilon$ спільним (communis) для спеціального розрізнення, ${ }^{(79)}$ яке вони самі обстоюють, і для загального (communis), ${ }^{(80)}$ яке разом $з$ томістами приймають, ${ }^{(81)}$ a $є$ незалежним від інтелекту формальним розрізненням 3 природи речі, ${ }^{82)}$ яке однак $\epsilon$ меншим за реальне і більшим за розумове, ${ }^{(83)}$ тому й називається проміжним.

\section{(1)Розділ 4. // [101 зв.] Про віртуальне розрізнення}

${ }^{(2)}$ Віртуальне розрізнення - це єдність, рівнозначна множинності, ${ }^{(3)}$ тобто віртуальне розрізнення між двома виявляється тоді, ${ }^{(4)}$ коли ці два $\epsilon$ чимсь одним актуально з боку речі, ${ }^{(5)}$ але й воно є чимось рівнозначним багатьом, ${ }^{(6)}$ котрі в іншому випадку реально актуально розрізняються. ${ }^{(7)}$ Наприклад, людина, хоча $\epsilon$ чимсь одним реально, ${ }^{(8)}$ маючи здатності (virtus) вегетативну, чуттєву і розумну, ${ }^{(9)}$ які разом 3 душею $\epsilon$ реально тотожними, - ${ }^{(10)}$ відповідає багатьом одушевленим істотам (animans) реально розрізненим. ${ }^{(11)}$ Називаємо віртуально

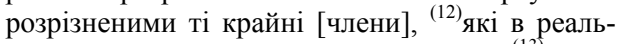
ності не містять жодного розрізнення, ${ }^{(13)}$ проте загалом становлячи одне й теж, ${ }^{(14)}$ вони водночас виявляють те саме, що виявляли б, ${ }^{(15)}$ якби були реально різними.

${ }^{(16)}$ Тому i предикати, ${ }^{(17)}$ які самі по собі утворюють контрадикцію, ${ }^{(18)}{ }_{3}$ огляду на це віртуальне розрізнення можуть, не спричинюючи жодної суперечності, виявлятися в одній і тій самі сущості (entitas), ${ }^{(19)}$ так, що ці предикати, самі по собі контрадикторні, ніби знімають суперечність 3 огляду на суб'єкт, ${ }^{(20)} \mathrm{i}$ без неї зливаються в одну й ту ж ідентичність ${ }^{\text {iv }}$. ${ }^{(21)}$ Це розрізнення називається також засадничим або радикальним, ${ }^{(22)}$ тому що створює засади (fundamentum) для інтелекту, щоб [той] абстрагував одну формальність (formalitas) від іншої. ${ }^{(23)}$ Деколи називають це розрізнення зовнішньо потенційним, ${ }^{(24)}$ або, що є одне й те саме, [розрізненням] виокремлюючого розуму, ${ }^{(25)}$ тому що віртуально розрізнювані формальності мають здатність бути розрізнюваними зовнішньо, ${ }^{(26)}$ тобто сприйматися реально розрізнюваними інтелектуальними актами.

\footnotetext{
${ }^{8}$ subiecti ] невиразно

${ }^{9}$ Preadicata distinctionis virtualis posita in uno subiecto exuunt contradictionem на полі

${ }^{10}$ distinctio ] від упорядника
} 


\begin{tabular}{|c|c|}
\hline $\begin{array}{l}{ }^{(27)} \mathbf{E x} \text { dictis colligitur virtualem } \\
\text { distinctionem esse rebus intrinsecam, } \\
{ }^{(28)} \text { quae realem imitatur quoad virtutem } \\
{ }^{(29)} \text { et munus fundandi praedicata intrinseca } \\
\text { contradictoria. }{ }^{(30)} \text { Praeter hanc autem } \\
\text { assignatur ab aliis virtualis distinctio } \\
\text { extrinseca, }{ }^{(31)} \text { quae sumitur penes ordinem } \\
/ / \text { [102] ad varios effectus seu varia } \\
\text { connotata ad quae refertur, }{ }^{(32)} \text { et tunc } \\
\text { distinguendi ratio desumitur ab extrinseco. } \\
{ }^{(33)} \text { Nam tunc eadem res per varios } \\
\text { conceptus comparatur ad distinctos } \\
\text { effectus, }{ }^{\left({ }^{(4)}\right)} \text { pro quorum diversitate diverso } \\
\text { quoque modo cognoscitur, (35) v.g. quando } \\
\text { dicitur: Homo est animal, eadem dicitur } \\
\text { concipi entitas ex parte obiecti (36) ac } \\
\text { quando dicitur: Homo est rationalis, } \\
{ }^{(37)} \text { cum hac tamen differentia, (38) quod } \\
\text { quando dicitur: Homo est animal } \\
{ }^{(39)} \text { comparatur entitas hominis in ordine ad } \\
\text { sensationem, (40) quando enim dicitur: } \\
\text { Homo est rationalis, (41) comparatur enim } \\
\text { eadem entitas hominis in ordine ad } \\
\text { discursum. (42) Unam hanc extrinsecam } \\
\text { virtualem distinctionem non esse } \\
\text { sufficientem patebitinferius. }\end{array}$ & 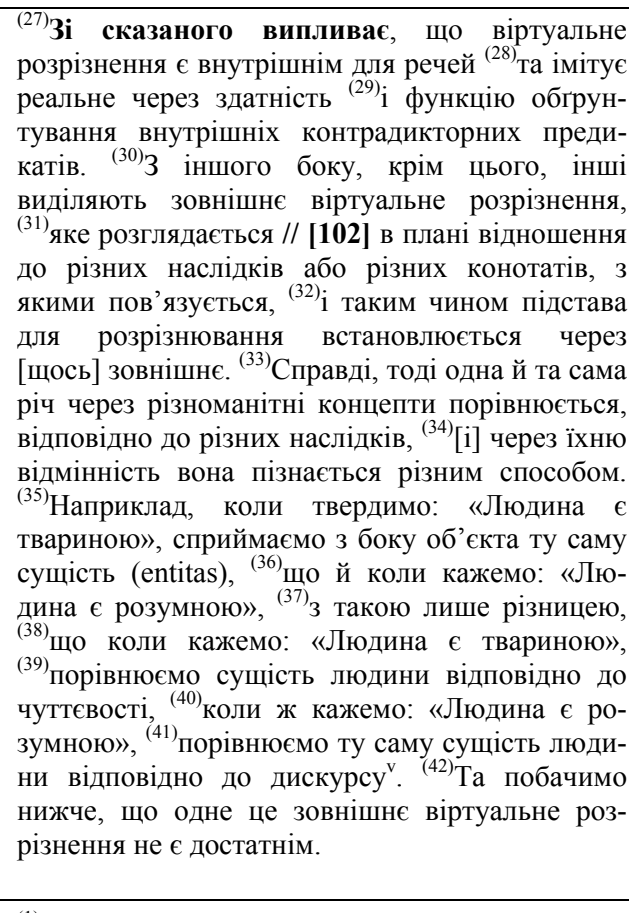 \\
\hline $\begin{array}{l}{ }^{(1)} \text { Caput 5. In quo distinctio scotistica } \\
\text { probatur }\end{array}$ & $\begin{array}{l}{ }^{(1)} \text { Розділ 5. У якому доводиться скотистичне } \\
\text { розрізнення }\end{array}$ \\
\hline $\begin{array}{l}{ }^{(2)} \text { Dari actu a parte rei inter aliqua } \\
\text { distinctionem formalem, }{ }^{(3)} \text { quae neque sit } \\
\text { realis propria, }{ }^{(4)} \text { neque enim rationis. }\end{array}$ & $\begin{array}{l}{ }^{(2)} 3 \text { боку речі між деякими актуально існує } \\
\text { формальне розрізнення, }{ }^{(3)} \text { яке не } \epsilon \text { ні справжнім } \\
\text { реальним, }{ }^{(4)} \text { ані розумовим. }\end{array}$ \\
\hline 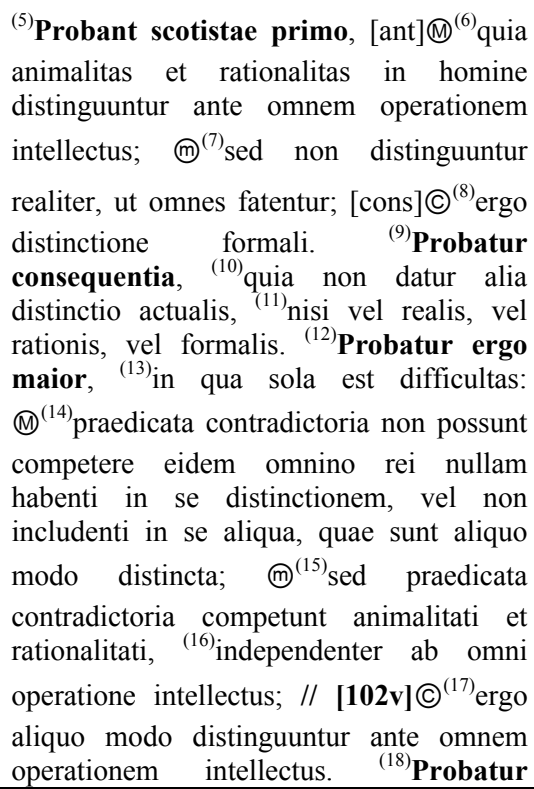 & 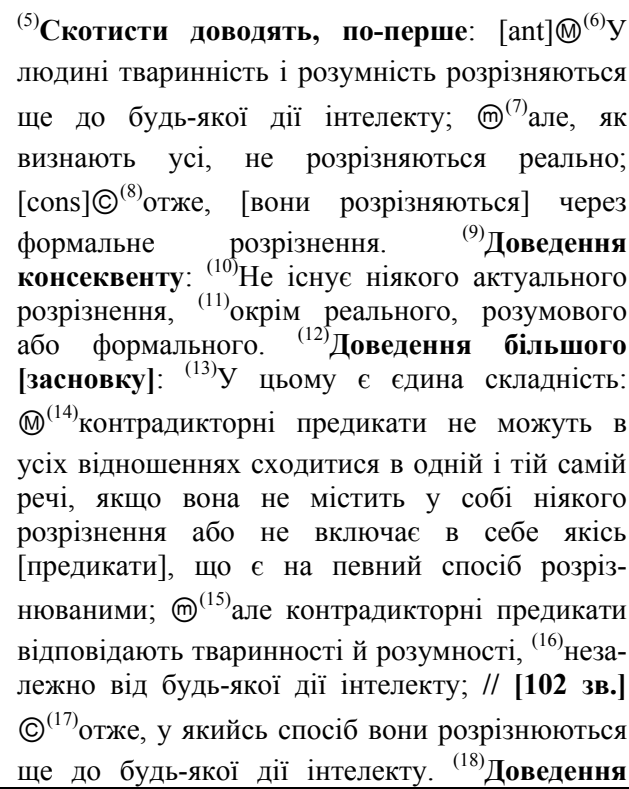 \\
\hline
\end{tabular}


maior ex primo principio, ${ }^{(19)}$ quia idem non potest simul esse et non esse, ${ }^{(20)}$ cuius ratio est quia esse et non esse sunt contradictoria, ${ }^{(21)}$ ergo eidem omnino indistinctae rei non possunt a parte rei competere praedicata contradictoria, ${ }^{(22)}$ alias destrueretur primum principium. ${ }^{(23)}$ Probatur minor, ${ }^{(24)}$ nempe quod contradictoria competunt animalitati et rationalitati, ${ }^{(25)}$ quia animalitas hominis habet convenientiam aliquam cum animalitate bruti, ${ }^{(26)}$ et rationalitas non habet convenientiam cum illa, item animalitas est principium sensationum, ${ }^{(27)}$ et potest esse in aliquo, in quo non possit esse rationalitas, ${ }^{(28)}$ sed nihil ex his potest dici de rationalitate, ${ }^{(29)}$ ergo aliquo modo distinguuntur ante omnem operationem intellectus.

$\begin{array}{llll}{ }^{(30)} \text { Probatur } & \text { secundo } & \text { [ant] ex } \\ \text { suppositione, } & { }^{(31)} \text { quod } & \text { risibilitas }\end{array}$
identificetur realiter homini, ${ }^{(32)}$ quod alibi patebit, ${ }^{(33)}$ risibilitas distinguitur ab homine ante omnem intellectus operationem non realiter; [cons] (34) ergo formaliter.

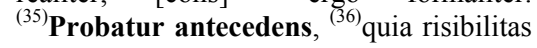
non est de essentia hominis et ${ }^{(37)}$ praesupponit ipsum hominem, ${ }^{(38)}$ a quo metaphysice pullulat, ${ }^{(39)}$ ergo distinguitur aliquo modo ab ipso a parte rei.

${ }^{(40)}$ Quidam philosophi volentes haec argumenta scotistarum solvere ${ }^{(41)}$ supponunt eandem omnem rem sine illa distinctione posse respicere effectus diversos, ${ }^{(42)}$ v.g. rem illam simplicissimam metaphysice, quae dicitur homo, ${ }^{(43)}$ posse respicere actum sensationis, ${ }^{(44)} \mathrm{v} . \mathrm{g}$. visionis aut auditionis, et actum rationis, ${ }^{(45)}$ v.g. intellectionem et discursum, (46) et secundum quod respicit priores actus, posse vocari uno nomine, ${ }^{(47)} \mathrm{v} . \mathrm{g}$. animalis, et definiri enim una definitione. ${ }^{(48)}$ Secundum vero quod respicit posteriores actus posse vocari alio nomine diverso, ${ }^{(49)}$ v.g. rationalis aut hominis et definiri etiam diversa definitione, ${ }^{(50)}$ quamvis in rei veritate sit eadem omnino res, sine ulla distinctione in se, quae explicetur et significetur utroque nomine et defintione, ${ }^{(51)}$ quatentus tamen // [103] respicit effectus diversos, qui possunt ab illa provenire. ${ }^{(52)}$ Hoc supposito dicunt nullam esse rationem, ${ }^{(53)}$ cur ita non sit de facto in homine, ${ }^{(54)}$ si potest ita fieri et nulla est enim ratio, cur non possit ita fieri. більшого [засновку] виходячи першого закону ${ }^{\text {vi. }}{ }^{(19)}$ те саме не може водночас бути і не бути, ${ }^{(20)}$ на тій підставі, що бути і не бути $\epsilon$ контрадикторним, ${ }^{(21)}$ отже, одній i тій самій цілком нерозрізнюваній речі не можуть з боку речі відповідати контрадикторні предикати, (22) інакше був би спростований перший закон. ${ }^{(23)}$ Доводиться менший [засновок], ${ }^{(24)}$ а саме, що контрадикторні [предикати] відповідають тваринності і розумності, (25) оскільки тваринність людини має певну сумірність 3 тваринністю нерозумної тварини, (26) а розумність не має 3 нею сумірності, так само тваринність $\epsilon$ принципом чуттєвості (27) $\mathrm{i}$ може існувати в чомусь, де не може бути розумності, ${ }^{(28)}$ але ніщо 3 цього не може стверджувати про розумність, ${ }^{(29)}$ отже, певним чином [контрадикторності] розрізняються ще до будь-якої дії інтелекту.

${ }^{(30)}$ Доведення друге: [ant] виходячи 3 припущення, ${ }^{(31)}$ що здатність сміятися реально ототожнюється 3 людиною (32) (що буде 3'ясоване в іншому місці), (33) здатність сміятися розрізняється від людини ще до будь-якої дії інтелекту не реально, [cons] (34) а отже формально. ${ }^{(35)}$ Доведення антецеденту: ${ }^{(36)}$ здатність сміятися не обумовлена сутністю людини, ${ }^{(37)}{ }_{i}$ передбачає саму людину, ${ }^{(38)}$ від якої метафізично походить; ${ }^{(39)}$ отже, вона розрізняється якимось чином від неї самої з боку речі.

${ }^{(40)}$ Деякі філософи, прагнучи спростувати цей доказ скотистів, ${ }^{(41)}$ виходять 3 того, що одна й та ж річ без цього розрізнення може мати відношення до різних дій. ${ }^{(42)}$ Наприклад, така метафізично найпростіша річ, якою вважається людина, ${ }^{(43)}$ може мати відношення до акту

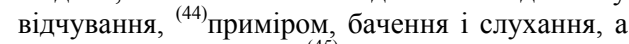
також дії розуму, ${ }^{(45)}$ наприклад, мислення (intellectio) i дискурсу (discursus), (46) $\mathrm{i}$ відповідно до того, що (secundum quod) вона має відношення до попередніх актів, може називатися однією назвою, ${ }^{(47)}$ наприклад, «тварини», i бути визначеною одним визначенням, (48), відповідно до того, що вона дотична (respicit) до подальших актів, може називатись іншою, відмінною, назвою, ${ }^{(49)}$ приміром, «розумної», або «людини», і бути визначеною за допомогою іншого визначення. ${ }^{(50)}$ Хоча насправді (in veritate rei) вона $є$ цілком тією самою річчю, без жодного розрізнення в собі, яка пояснюється i позначається 3 допомогою обох назв і визначень, ${ }^{(51)}$ оскільки // [103] дотична до різних дій, джерелом яких вона може бути. ${ }^{(52)}$ Виходячи 3 цього (supposito), вони стверджують, що немає жодної підстави, ${ }^{(53) щ о б ~ т а к ~ н е ~}$ 


\begin{tabular}{|c|c|}
\hline & $\begin{array}{l}\text { відбувалося фактично (de facto) на прикладі } \\
\text { людини, }{ }^{(54)} \text { якщо так може бути, і немає } \\
\text { насправді жодної підстави, чому б так не могло } \\
\text { бути. }\end{array}$ \\
\hline $\begin{array}{l}{ }^{(55)} \text { Respodent itaque in forma ad } \\
\text { argumentum primum distinguendo } \\
\text { maiorem: }{ }^{(56)} \text { animalitas, secundum quid } \\
\text { connotat, }{ }^{(57)} \text { aut secundum quid respicit } \\
\text { sensationem, }{ }^{(58)} \text { distinguitur a rationalitate, } \\
{ }^{(59)} \text { secundum quid respicit actus rationales } \\
\text { - concedunt; }{ }^{(60)} \text { secundum se et absolute } \\
\text { distinguuntur }- \text { negant maiorem. } \\
{ }^{(61)} \text { Similiter secundae probationis } \\
\text { antecenens distinguunt sic: }{ }^{(62)} \text { risibilitas, } \\
\text { secundum quid connotat risum, est } \\
\text { distincta ab homine, }{ }^{(63)} \text { secundum quid } \\
\text { connotat homo, actus rationalis }- \\
\text { concedunt, absolute et secundum se - } \\
\text { negant antecedens. }{ }^{(65)} \text { Ad cuius } \\
\text { probationem respondent distinguendo } \\
\text { antecedens: risibilitas, secundum quid } \\
\text { connotat risum, praesupponit hominem }{ }^{11} \text {, } \\
{ }^{(66)} \text { secundum quid connotat }{ }^{12} \text { actus } \\
\text { rationales et non est de essentia ipsius - } \\
\text { condedunt, }{ }^{(67)} \text { secundum se et absolute - } \\
\text { negant antecedens. }\end{array}$ & 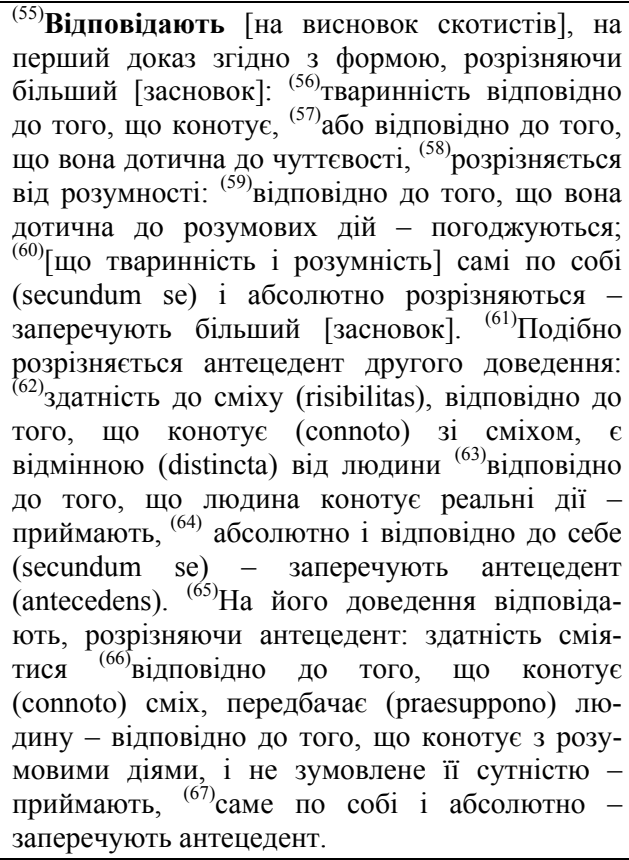 \\
\hline $\begin{array}{l}{ }^{(68)} \text { Contra totam hanc replicam agunt } \\
\text { scotistae }{ }^{(69)} \text { concedendo quidem } \\
\text { definitiones, quibus definiretur res, }{ }^{(70)} \text { ut } \\
\text { respiceret distinctos effectus, }{ }^{(71)} \text { aut ut } \\
\text { consideraretur in ordine ad illos, }{ }^{(72)} \text { non } \\
\text { necessario arguere distinctionem } \\
\text { formalem, }{ }^{(73)} \text { sed negant diversas } \\
\text { definitiones, }{ }^{\left({ }^{(7)}\right)} \text { quibus res definirentur } \\
\text { secundum se, }{ }^{(75)} \text { non arguere distinctionem } \\
\text { formalem. }{ }^{(76)} \text { Dicunt autem scotistae } \\
\text { sufficiens esse signum ad colligendum, } \\
{ }^{(77)} \text { quod una et eadem formalitas non } \\
\text { definiatur, quatenus respicit effectus } \\
\text { distinctos, diversis definitionibus, }{ }^{(78)} \text { si una } \\
\text { ex illis definitionibus, possit competere } \\
\text { alicui, }{ }^{(79)} \text { cui altera definitio comptetere } \\
\text { non possit, }{ }^{(80)} \text { v.g. quia definitio, quae datur } \\
\text { de animali, }{ }^{(81)} \text { potest competere alicui, cui } \\
\text { definitio rationalitatis non competit; // } \\
{\left[\mathbf{1 0 3 v}{ }^{(82)} \text { propterea bene colligi potest non }\right.} \\
\text { esse eandem formalitatem, }{ }^{(83)} \text { quae utraque } \\
\text { definitione definitur. }{ }^{(84)} \text { Dicunt ulterius, }\end{array}$ & 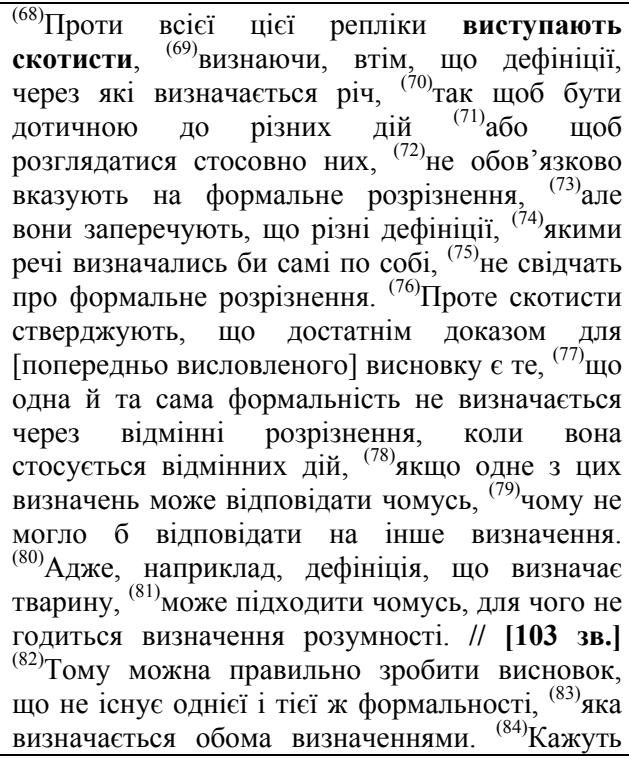 \\
\hline
\end{tabular}

${ }^{11}$ praesupponit hominem ] виправлено, було est distincta ab homine

12 закреслене слово homo 
quod si res non possent definiri absolute, ${ }^{(85)}$ nisi tamen non respicientes aliquem effectum, ${ }^{(86)}$ tum non definirentur propria definitione essentiali ${ }^{(87)}$ et sic nulla esset definitio essentialis propria alicui rei, ${ }^{(88)}$ quod esset inconveniens.

\section{${ }^{(1)}$ Caput 6. In quo probatur distinctio} virtualis

${ }^{(2)}$ Dictum est, quod virtualis distinctio sit eminentia rei, ${ }^{(3)}$ quae unica existens plures perfectiones continet in aliquo esse, ${ }^{(4)}$ nunc eam distinctionem dari.

\section{${ }^{(5)}$ Probatur primo, quia res aliqua, quanto} est superior et eminentior, tanto plures perfectiones unit, quam inferior. ${ }^{(6)}$ Unde in uno ente simplici inveniuntur rationes seu perfectiones, (7) quae inferioribus entis diversa entia constituerent, ${ }^{(8)}$ et inde intellectus uno conceptu attingendo unam ${ }^{(9)}$ et alio aliam rationem distinguit illas et dividit.

\section{${ }^{(10)}$ Probatur secundo: Voluntas hominis} ex natura sua praesupponit intellectum, siquidem in homine nihil sit prius libere volitum, nisi prius cogntitum; ${ }^{(11)}$ ac proinde voluntas pendet ab intellectu; ${ }^{(12)}$ ergo voluntas et intellectus a parte rei virtualiter differunt, ${ }^{(13)}$ cum idem ut idem non possit se ipso esse prius et a se ipso pendere.

${ }^{(14)}$ Probatur tertio: [ant] Homo, ut est aptus concipi distincte per modum animalis, ${ }^{(15)}$ non est formaliter aptus concipi per modum viventis; [cons] ${ }^{(16)}$ ergo in homine ratio viventis et ratio animalis distinguuntur virtualiter. ${ }^{(17)}$ Probatur consequentia axiomate: // [104] idem nam ut idem semper aptum est obiici intellectui idem, ${ }^{(18)}$ nam si idem ut idem posset obiici diversis specie actibus intellectus, ${ }^{(19)} \mathrm{hi}$ actus essent eiusdem speciei quandoquidem actus specificantur $a b$ obiectis $^{13}$.

${ }^{(20)}$ Probatur quarto argumento theologico: [ant] ${ }^{(21)}$ Datur distinctio etiam in Divinis; [cons] ${ }^{(22)}$ ergo simpliciter virtualis distinctio verificatur. ${ }^{(23)}$ Probatur antecedens: Essentia Divina est далі, що якби речі не можна було визначити абсолютно, ${ }^{(85)}$ навіть якщо вони мають відношення до якоїсь дії, ${ }^{(86)}$ то вони не визначались би власною суттєвою дефініцією, ${ }^{(87)}$ тоді б не існувало власного суттєвого визначення для кожної речі, ${ }^{(88)}$ що було б неприйнятним.

${ }^{(1)}$ Розділ 6. У якому доводиться віртуальне розрізнення

${ }^{(2)}$ Сказано, що віртуальне розрізнення $\epsilon$ довершеною властивістю (eminentia) речі, ${ }^{(3)}$ яка існуючи як єдина у своєму роді вміщує багато досконалостей (perfectio) в певному бутті, ${ }^{(4)}$ таким чином таке розрізнення існує.

${ }^{(5)}$ Доведення перше: Якась річ, що вищою (superior) і довершенішою (eminentior) вона $\epsilon$, то більше об'єднує досконалостей, порівнюючи 3 нижчою. ()Через це в одному простому сущому відкриваються смисли (ratio) або досконалості (perfectio), ${ }^{(7)}$ які у нижчих сущих конституювали різні сущі, ${ }^{(8)}$ тому коли інтелект в одному концепті торкається одного, (9) а в іншому - іншого смислу, він розрізняє їх i поділяє.

${ }^{(10)}$ Доведення друге: Людська воля за своєю природою попередньо спирається на інтелект, тому в людині тільки те $є$ вільно побажаним, що попередньо було пізнане; ${ }^{(11)}$ таким чином, воля залежить від інтелекту; ${ }^{(12)}$ отже, воля і інтелект 3 боку речі (a parte rei) віртуально розрізняються, ${ }^{(13)}$ адже однакове як однакове не може бути ранішим від себе самого і від себе самого залежати.

${ }^{(14)}$ Доведення третс: [ant] Людина, оскільки іiі можна окремо сприймати як тварину, не

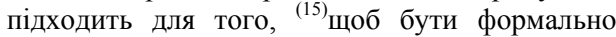
сприйнятою на спосіб живої істоти; [cons] (16) отже, в людині начало (ratio) живої істоти $\mathrm{i}$ начало тварини розрізняються віртуально. ${ }^{(17)}$ Доведення консеквенту через аксіому: // [104] «однакове як однакове завжди здатне поставати перед інтелектом однаковим», (18) адже якби однакове як однакове могло ставати об'єктом за допомогою різних за видом актів інтелекту, ${ }^{(19)}$ тоді б ці акти були одного й того самого виду, оскільки вони визначаються об'єктами.

${ }^{(20)}$ Доведення четверте через теологічний доказ: [ant] ${ }^{(21)}$ Існує також [це] розрізнення у Святій Трійці, [cons] ${ }^{(22)}$ отже, безумовно підтверджується віртуальне розрізнення. ${ }^{(23)}$ Доведення антецеденту: Божественна

${ }^{13}$ obiectis ] нечітко 
communicabilis; ${ }^{(24)}$ Paternitas vero Divina secundum se non est communicabilis ${ }^{14}$; ${ }^{(25)}$ egro est aliqua distinctio virtualis a parte rei inter essentiam Divinam et Paternitatem. ${ }^{(26)}$ Probatur consequentia, quia si nulla prorsus sit distinctio virtualis inter ipsa, ${ }^{(27)}$ impossibile est, quin quicquid actu convenit uni a parte rei formaliter conveniat alteri; ${ }^{(28)}$ est nam inimaginabile, si nulla esset distinctio a parte rei inter Paternitatem et essentiam, ${ }^{(29)}$ et essentia esset a parte rei formaliter Paternitas et e converso, ${ }^{(30)}$ quin quicquid praedicetur de essentia preadicaretur de paternitate et e converso, ${ }^{(31)}$ ergo cum communicari et identificari Filio praedicetur de essentia, ${ }^{(32)}$ etiam idem deberet praedicari de Paternitate ${ }^{(33)}$ et sic Pater non distingueretur realiter a Filio, ${ }^{(34)}$ quod esset contra fidem.

${ }^{(1)}$ Caput 7. In quo concluditur distinctio virtualis et scotistica

${ }^{(2)}$ Ex probationibus utriusque distinctionis prospicue patet virtualem et scotisticam iisdem inniti fundamentis, ${ }^{(3)}$ proinde videntur in rei veritate secum coincidere et solis verbis discrepare; // [104v] ${ }^{(4)}$ nobis vero cum expediat non de verbis contendere, sed rem intendere.

${ }^{(5)}$ Idcirco concludimus has distinctiones a se non differri.

${ }^{(6)}$ Conclusio probatur primo, ${ }^{(7)}$ nam quando dicis, quod v.g. animalitas et rationalitas distinguuntur virtualiter, ${ }^{(8)}$ vel dicis, quod animalitas non sit [realiter] ${ }^{15}$ rationalitas, ${ }^{(9)}$ vel dicis, quod animalitas sit formaliter rationalitas a parte rei, ${ }^{(10)} \mathrm{si}$ primum dicis, asseris esse distinctionem ex natura rei formalem, ${ }^{(11)}$ quia quando dicis, quod distinguantur formaliter, ${ }^{(12)}$ nihil aliud intendis, quam quod a parte rei animalitas non sit rationalitas, nec econtra; ${ }^{(13)}$ ergo si per distinctionem virtualem hoc ipsum intelligitur, ${ }^{(14)}$ qui hanc concedit, ${ }^{(15)}$ debet concedere et illam. ${ }^{(16)} \mathrm{Si}$ secundum dicas, ${ }^{(17)}$ hoc obstabit, ${ }^{(18)}$ quod impossibile sit, ${ }^{(19)}$ ut eidem omnino rei sine ulla distinctione independenter $a b$ intellectu praedicata contradictoria conveniant; сутність може передаватися (communicabilis), (24) а Божественна Отцевість сама по собі (secundum se) не може передаватися, ${ }^{(25)}$ отже, 3 боку речі існує віртуальне розрізнення між Божественною сутністю і Отцевістю. (26)Доведення консеквенту: Якщо між ними немає зовсім ніякого віртуального розрізнення, ${ }^{(27)}$ то неможливо, щоб будь-що, що актуально відповідає одному, з боку речі формально не відповідало іншому; ${ }^{(28)}$ бо неможливо уявити, щоб, якби не було ніякого розрізнення з боку речі між Отцевістю і сутністю [Бога], ${ }^{(30)_{i}}$ сутність була 6 формально 3 боку речі

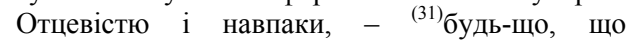
предикувалося б до сутності, не предикувалося б також i до Отцевості, i навпаки. ${ }^{(32)}$ Отже, оскільки «бути передаваним» і «ідентифікуватися з Сином» предикується до сутності, ${ }^{(33)}$ то це саме також мало б предикуватися до Отцевості, ${ }^{(34)}$ таким чином Отець не відрізнявся би реально від Сина, ${ }^{(35)}$ що було б проти віри.

${ }^{(1)}$ Розділ 7. У якому робиться висновок щодо віртуального і скотистичного розрізнення

${ }^{(2)} 3$ доведення обох розрізнень стає зрозуміло, що віртуальне i скотистичне [розрізнення] грунтуються не однакових засадах (fundamenta); ${ }^{(3)}$ тому очевидно, що насправді в реальності вони між собою збігаються, а лишень у словах розрізняються; // [104 3в.] ${ }^{(4)}$ однак для нас корисно не про слова сперечатися, але суть зрозуміти.

(5)3 огляду на це, робимо висновок, що ці розрізнення між собою не відрізняються.

${ }^{(6)}$ Перше доведення висновку: ${ }^{(7)}$ Коли кажеш, що, наприклад, тваринність i розумність розрізняються віртуально, ${ }^{(8)}$ або коли кажеш, що тваринність не $\epsilon$ [реально] розумністю, ${ }^{(9)}$ або кажеш, що тваринність $\epsilon$ формально розумністю з боку речі (a parte rei), $-{ }^{(10)}$ [то], якщо стверджуєш перше, то визнаєш формальне розрізнення 3 природи речі, (11) тому що, коли кажеш, що вони розрізнюються формально, ${ }^{(12)}$ ніщо інше не маєш на увазі, як те, що 3 боку речі тваринність не $\epsilon$ розумністю, а не навпаки. ${ }^{(13)}$ Отже, якщо під віртуальним розрізненням розуміємо те саме, (14) той, хто визнає це [віртуальне розрізнення], ${ }^{(15)}$ повинен погодитися i 3 іншим [3 формальним розрізненням]. ${ }^{(16)}$ Якщо стверджуєш друге, ${ }^{(17)}$ то будеш заперечувати те, ${ }^{(18)}$ що неможливо, ${ }^{(19)}$ щоб в одній і тій самій речі загалом без будь-якого

14 NB на полі

${ }^{15}$ realiter ] y рукописі formaliter 
(20) iam vero cum de facto conveniunt,

${ }^{(21)}$ clarum est ea aliquo modo distingui sive virtualiter sive formaliter.

розрізнення незалежно від інтелекту збігалися контарадикторні предикати, ${ }^{(20)}$ одначе вже, коли вони де факто збігаються, ${ }^{(21)}$ ясно, що вони в якийсь спосіб розрізняються або віртуально або формально.

${ }^{(22)}$ Confirmatur, quia vel distinctio virtualis est independenter $\mathrm{ab}$ intellectu vel non est. ${ }^{(23)} \mathrm{Si}$ primum, ergo habetur aliqua distinctio a parte rei inter animalitatem et rationalitatem, (24) quocunque nomine vocetur. ${ }^{(25)} \mathrm{Si}$ secundum, ergo dictum male est, ${ }^{(26)}$ quod illa sit a parte rei fundamentum distinctionis rationis ratiocinatae.

${ }^{(27)}$ Probatur secundo: [ant] Non magis una illarum distinctionum repugnat simplicitati et unitati entis, quam altera, [cons] ${ }^{(28)}$ ergo sunt quod idem. // [105] ${ }^{(29)}$ Probatur antecedens, quia aeque manet ens idem realiter admissa utraque distinctione, ${ }^{(30)}$ et licet sit quaedam disconvenientia in terminis, ${ }^{(31)}$ quod scotistica videatur plus dicere, ${ }^{(32)}$ cum vocatur formalis actualis, ${ }^{(33)}$ virtualis vero minus, ${ }^{(34)}$ cum vocatur potentialis fundamentalis. ${ }^{(35)}$ Tamen et in vocibus erit convenientia, ${ }^{(36)}$ si sano modo intelligantur, ${ }^{(37)}$ nam cum prima dicitur actualis formalis, ${ }^{(38)}$ intelligitur, quod actu sint illae formalitates in re identificatae illi, ${ }^{(39)}$ quod ipsum non negat et virtualis, ${ }^{(40)}$ cum admittit in re contineri perfectiones plures, ${ }^{(41)}$ potentialis autem et fundamentalis ex eo dicitur, ${ }^{(42)}$ quod perfectiones illae possint concipi ut divisae et ut distinctae.

${ }^{(22)}$ Підтвердження: Віртуальне розрізнення існує або незалежно від інтелекту, або [взагалі] не існує. ${ }^{(23)}$ Якщо перше, [то,] отже, має місце якесь розрізнення 3 боку речі між тваринністю $\mathrm{i}$ розумністю, ${ }^{(24)} я$ бк би воно не називалося.

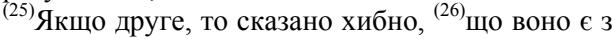
боку речі засадою для розрізнення мисленого розуму.

${ }^{(27)}$ Доведення друге: [ant] Одне 3 тих розрізнень суперечить простоті i єдності сущого не більше, ніж інше; [cons] ${ }^{(28)}$ отже, вони є чимось тотожним. // [105] ${ }^{(29)}$ Доведення антецеденту: Суще залишається реально одним і тим самим, якщо припустити обидва розрізнення, ${ }^{(30)}$ хоча існує деяка невідповідність у термінах, тому що, (31) як видається, скотистичне [розрізнення] пойменовує [щось] більше, ${ }^{(32)}$ оскільки називається формальним актуальним, ${ }^{(33)}$ а віртуальне - менше, ${ }^{(34)}$ оскільки називається потенційним засадничим. ${ }^{(35)}$ Однак і у словах має буде відповідність, ${ }^{(36)}$ якщо правильно зрозуміти. ${ }^{(37)}$ Адже коли перше називається актуальним формальним, ${ }^{(38)}$ мається на увазі, що ті формальності актуально наявні в речі (in re) та ідентифіковані 3 нею; ${ }^{(39)}$ це саме не заперечує і віртуальне, ${ }^{(40)}$ бо припускає, що в них містяться численні досконалості (perfectiones), ${ }^{(41)}$ а потенційним i

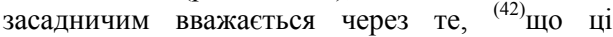
досконалості можуть сприйматися як розділені (divisus) і розрізнені (distinctus).

${ }^{(43)}$ Probatur tertio, ${ }^{(44)}$ quia eadem argumenta adversariorum, ${ }^{(45)}$ quae pugnant contra formalem, ${ }^{(46)}$ pugnant enim contra virtualem, ${ }^{(47)}$ et quae solvuntur per formalem, ${ }^{(48)}$ solvuntur etiam per virtualem, ${ }^{(49)}$ ut mox patebit; ${ }^{(50)}$ ergo signum est has distinctiones esse a parte rei idem.

${ }^{(43)}$ Доведення третє: ${ }^{(44)} \mathrm{Ti}$ самі аргументи супротивників, ${ }^{(45)}$ які заперечують формальне розрізнення, ${ }^{(46)}$ заперечують також і віртуальне, ${ }^{(47)} \mathrm{a}$ які розв'язуються за допомогою формального, ${ }^{(48)}$ розв'язуються також і через віртуальне, ${ }^{(49)}$ що скоро стане очевидним; (50) отже, це доказ того, що ці розрізнення $€ 3$ боку речі тим самим.

\section{ПРИМІТКИ}

'Напис на полі: «Реальним є розрізнення між ними».

ii Напис на полі: «Не між двома сущостями, а між двома цілковитими сущими».

iii Напис на полі: «Однак формальне розрізнення виявляється між двома сущостями, що містяться в одному сущому».

iv Напис на полі: «Предикати віртуального розрізнення, що містяться в одному суб'єкті, позбавляться контардикції».

v «Discursus», тобто вміння говорити, є ознакою розумності. Тобто коли постає питання, на підставі чого вважається, що людина має розум, а тварина його не має, 
то схоластичні філософи би відповіли, що на підставі дискурсу. Людина користується мовою, а тварина - ні.

vi Закону контрадикції. 